\title{
Dynamics of Sexual Harassment on Social Media
}

\section{Virgin Suciyanti Maghfiroh ${ }^{1}$, Faqihul Muqoddam²}

${ }^{1}$ Airlangga University, Surabaya Indonesia, $₫$ virgin.suciyanti.maghfiroh-2018@psikologi.unair.ac.id

${ }^{2}$ Airlangga University, Surabaya Indonesia, \faqihul.muqoddam-2018@psikologi.unair.ac.id

\begin{abstract}
Sexual harassment is a currently netizen's habit on social media. Almost all of their comments on social media contain words to abuse. This study was conducted with the aim of analyzing the forms of sexual harassment and identifying the factors of sexual harassment on social media. This study uses a qualitative method of narrative tradition with a focus on investigating sexual harassment that occurs on social media. Data collection methods are carried out by observing comments of netizens. The characteristics of the comments that chosen in this study are those written on Instagram and point to the element of sexual harassment. The results show that sexual harassment on social media is happen with; 1 . directly (explicitly), 2. indirectly (implicitly) according to the meaning of the sentence. Then, the factors of sexual harassment on social media are; 1 . netizens are looking for attention (as evidenced by accounts that are used only fake accounts), 2. photo content or account owner captions that lead netizens to harass. Suggestions based on this study are the need to develop psychoeducation for adolescents and families both as subjects and victims so as to avoid sexual harassment behavior.
\end{abstract}

Keywords:Sexual Harassment, social media, qualitative narrative

\section{Introduction}

Social media is the most popular online activity used by individuals today. This is proven by the increasing number of social media users from time to time and from year to year. Statisca.com (2018) gets social media user data increasing from 2010 to 2021. The obtained data shows that social media users in 2017 totaling 2.46 billion are expected to increase sharply to 2.77 users in 2019. The increasing number of users has an impact on the popularity of social media as an online social network in the world. 


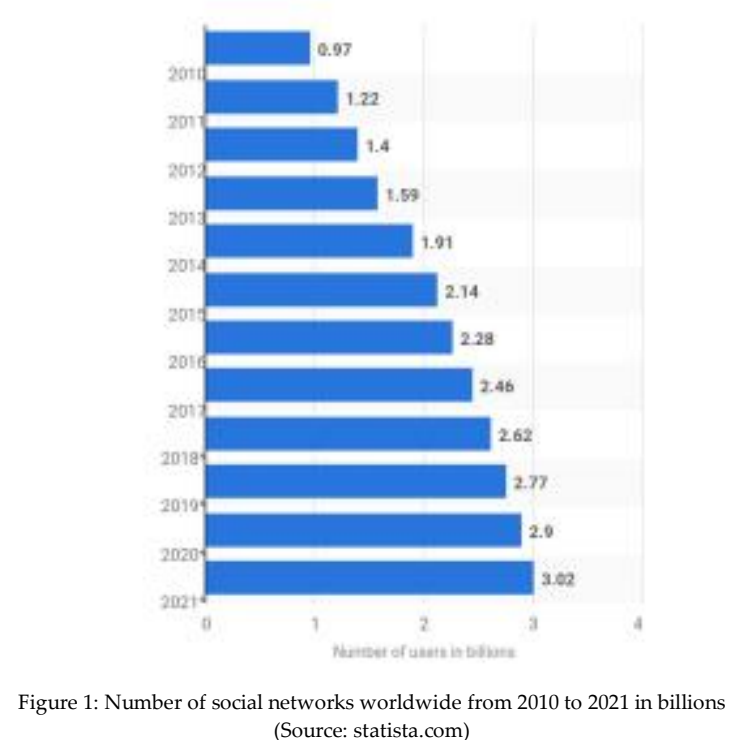

Some kinds of social media are popular among us such as Instagram, WhatsApp, Facebook, Twitter, Snapchat and some online media that used in communicating with others. The results of a survey conducted by Aljohani, Nisbet, \& Blincoe (2016) revealed that Instagram was one of the most sought after social media. Of the total 415 respondents, Instagram users reached 253 people. Popularity of instagram also supported by Alhabash \& Ma (2017) which states that from the results of their research on 396 students, the intensity of Instagram users is still superior compared to Snapchat, Facebook and Twitter.

The use of social media based on the user's satisfaction in using the network. This is in accordance with the opinion of Keipi, Koiranen, Koivula, \& Rasanen (2018) who found that the use of social media, especially Instagram and WhatsApp, has a positive relationship to the level of individual satisfaction. The more they use social media, the more satisfaction they feel. Individual satisfaction is part of the personality factors they experience. Because, all activities that occur in the use of social media reflect personality characteristics experienced by individuals (Waheed, Anjum, Rehman \& Khawaja, 2017).

Instagram is one of the social media that has the characteristics of displaying photos / images, captions, instories, and comment fields. Of course the most important thing that Instagram offers is the photo display feature. The intensity of the use of Instagram has an impact on the individual's objectivity. Someone tends to make Instagram become a self-reflection and modeling, for example imitating photos of celebrities that they like and internalize themselves (Fardouly, Willburger, \& Vertanian, 2017).

Instagram has an impact on forming or taking photos of individuals, especially women. They feel interested in the world of photography so that their photos can be displayed on Instagram and get attention from the public. Instagram doesn't always have a positive impact, it can also have negative effects such as social pressure that forces someone to change their appearance (Sharifi, Omidi, \& Marzban, 2016). But in reality, social media does not only provide benefits in its application. The use of social media has a negative impact in relation to social relations. The impact experienced by social media users in the form of harassment, online isolation and loneliness (Ryan, Allen, Gray, \&McInerney, 2017). Harassment in social media tends to involve sexual elements in its application. A 
study of middle-class students shows that they access the internet in an effort to obtain information about sex-related matters (Gorkemli, 2017).

The rise of sexual harassment that occurs on social media, especially Instagram, raises a question, namely how is the process of sexual abuse occurring on social media? However, to answer these questions it is necessary to describe the forms of sexual harassment on social media and the factors that cause sexual harassment on social media. Of course this discussion is very interesting to describe in this study, considering that social media users, especially Instagram, have experienced a rapid increase over time.

\section{Method}

This research on sexual harassment dynamics in social media uses the tradition of qualitative research through a narrative approach. This approach method are used because it is descriptive and comes from the narrative of individual experiences (Creswell, 2015).

The research procedure follows the view of Neuman (2007) which is divided into seven stages, namely choosing the topic, focusing the questions, determining the research design, collecting data, analyzing data, interpreting the data, and ended with making research reports.

This study focuses on investigating the comments of social media users on Instagram. Involving Instagram user comments as a source of data is based on Carman's (2018) statement which reveals that Instagram has become one of the most widely used social media by humans. According to him, Instagram users have reached 1 (one) billion worldwide.

The process of collecting data by observing the comments of Instagram users in responding to several posts that contain sexual elements, both male and female users of Instagram. We do data mining every time by observing and looking at a number of Instagram user comments that tend to lead to sexual harassment of account owners with posts showing an open body and tend to have sexual characters.

The data obtained from the observations were then analyzed using thematic analysis. Braun \& Clarke (2006) explained that in using thematic analysis in psychology studies must do six steps, namely familiarizing themselves with data, initializing code, looking for themes, reviewing themes, defining and naming themes, and submitting reports from the results of the analysis.

\section{Results and Discussion}

Social media is a communication tool that functions to connect individuals with others. Individuals use social media for various purposes ranging from buying and selling business activities and looking for new friends or old friends. Social media can unite many individuals who are separated between distance and time getting closer. Communication between parts of the world becomes easier with social media. However, the current condition of some individuals abusing the function of social media. Some people use it as a fraudulent medium to bullying. Harassment in social media tends to involve sexual elements in its application. The impact experienced by social media users can be in the form of harassment, online isolation and loneliness (Ryan, et al. 2017). 
Focusing on this research, social media that is discussed is Instagram. Where Instagram has several photo, video, instastory upload features; text, live broadcast, normal, boomerang, superzoom, rewind, hands-free (Instagram application, 2018). Some of these features have a function to show friends or relationships about activities and feelings that are being experienced by the account owner. From the upload of some features, this ultimately leads to bullying for account owners. The culpritsare followers who do not like the owner of the account commonly referred to as haters.

This study looked at several social media accounts including the account @jonatanchristieofficial whose owner is an Indonesian badminton athlete who won a gold medal at the 2018 Asian Games after defeating Chou Tien Chen at Istora Gelora Bung Karno (GBK) on August 28 (Detik.com, 2018 ) The other account is @nashwaaaz whose owner is a 2018 Indonesian Idol Junior contestant who is famous for her beautiful face that makes the audience even the jury impressed.

\section{Form of Sexual Harassment on Social Media}

The results showed that the form of sexual harassment on social media was carried out in two ways;

1. Clearly (explicitly)

This form of sexual harassment is said directly because netizen comments are directly to the point against the private part of the account owner. This can be seen in the post below:
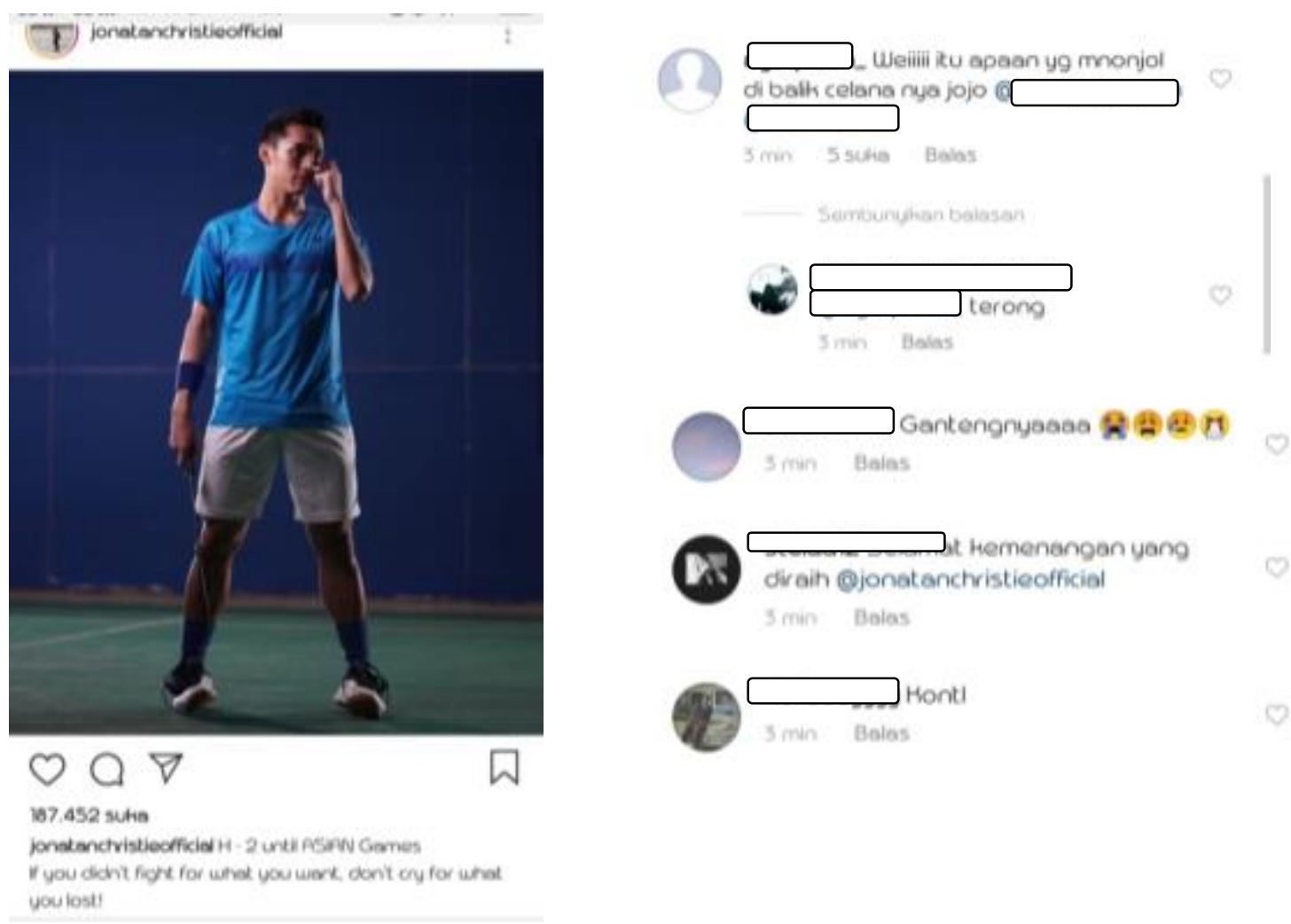

Based on the photo post above actually the account owner does not show things about sexuality. Even in the photo, the included caption is "H-2 until ASIAN Games if you don't fight for what you want, don't cry what you lost". The statement is only a sentence of enthusiasm and motivation for Jonathan himself. However, what's interesting is the response of some netizens which they discuss male sensitive organs. According to Aprilia (2017), forms of sexual harassment on social media can 
be; praising body shapes, throwing personal questions (regarding personal organs), sending photos, links or porn videos, asking victims to send naked photos or videos, threats of rape, solicitation of sexual relations, and acknowledging making the victim's body a sexual image.

Sexual harassment can also be a form of comments that tempt and disturb and make the account owner uncomfortable is something that is common in the context of the use of social media, especially Instagram. Not much different from whistles, words and touches that are usually done by unscrupulous sexual abuse in the real world. Sexual harassment of individuals can also occur on social media.

2. Indirect (implied) is judged based on the meaning of the sentence

Indirect forms of sexual harassment in this study can be seen from some of the netizen comments below;
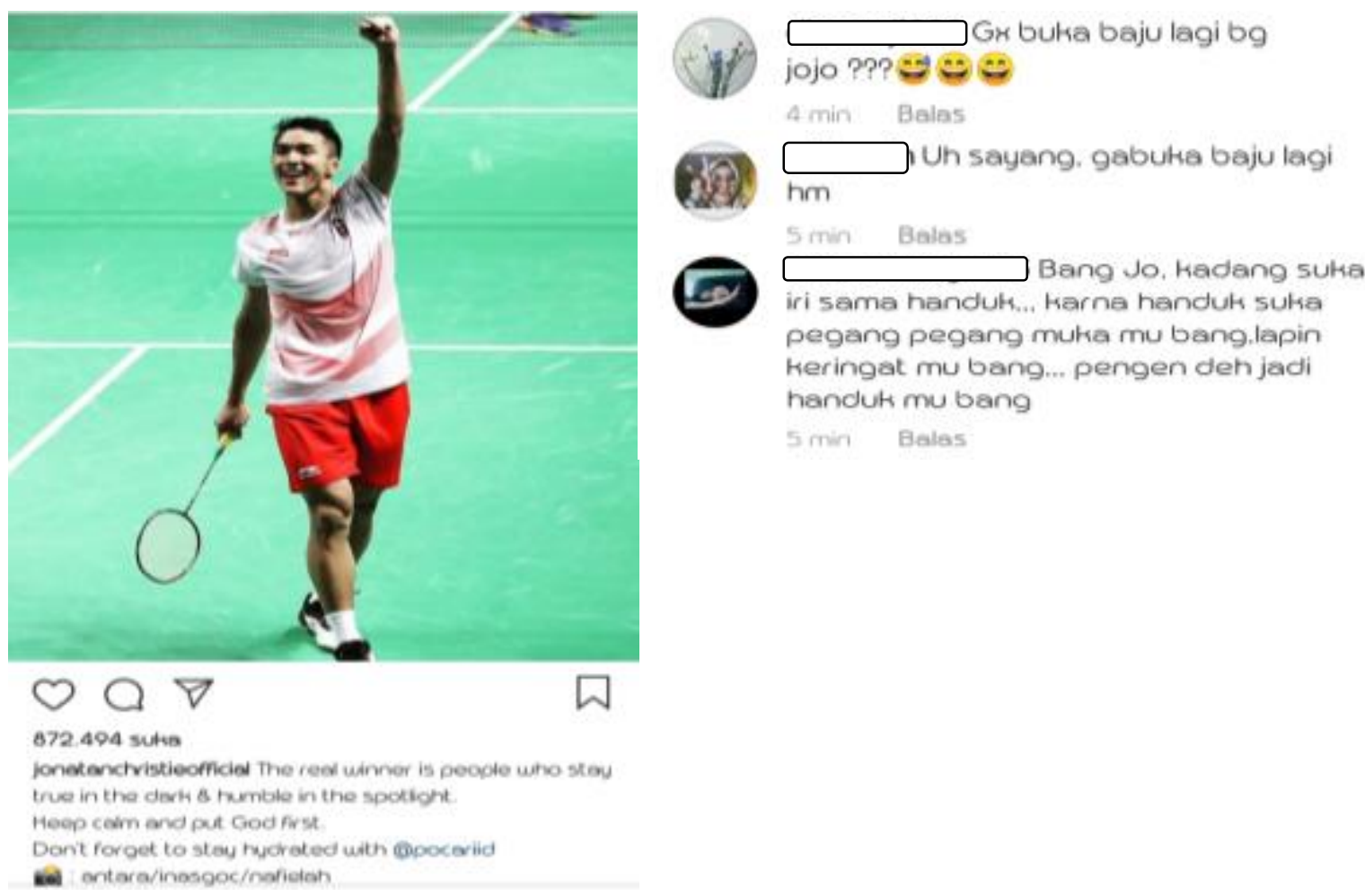

iri sama handuk... harne handuk suka pegang pegang muka mu bang.lapin heringat mu bang... pengen deh jadi handut mu bang $5 \mathrm{~min}$ Balas

In the photo above, the account owner writes the caption "The real winner is people who stay true this is the dark \& humble in the spotlight. Keep calm and put God first. In the upload, the account owner just wants to show who is a winner. However some comments actually ask Jonathan to undress again instead of discuss what was in the upload. This has been considered a form of sexual harassment because the comment has a tempting nature. Even though before, the owner of the account when winning the semifinal match had opened his shirt as a form of celebration to express his joy and happiness. This makes the audience, mostly women, shout (Wening, business sports, 2018). Should be in writing comments, netizens are wiser in accordance with the caption and moment of the account owner so that it is more polite.

Sexual harassment is an undesirable and unwanted behavior by each individual because it will cause disruptions. If this is done intentionally and repeatedly, it will cause discomfort, and will 
personally make social media users as targets of sexual harassment (Schenk, 2008). Behaviors that can be classified as acts of sexual harassment are like coercion of sexual activity, statements demeaning sexuality or sexually orientedjokes, requests for sexual acts favored by the perpetrator as well as speech or behavior that connotes sexually, these actions can be delivered directly or indirectly (implicitly) (Friska, 2017).

\section{Factors for Sexual Harassment on social media}

The next result in this study is about the factors of sexual abuse on social media, namely;

\section{Looking for attention}

Netizens commit sexual harassment on social media only to seek attention from account owners and the possibility of wanting to get many followers. It can be seen from one of the accounts below that writing comments which lead to sexual harassmentwhich is a fake account.

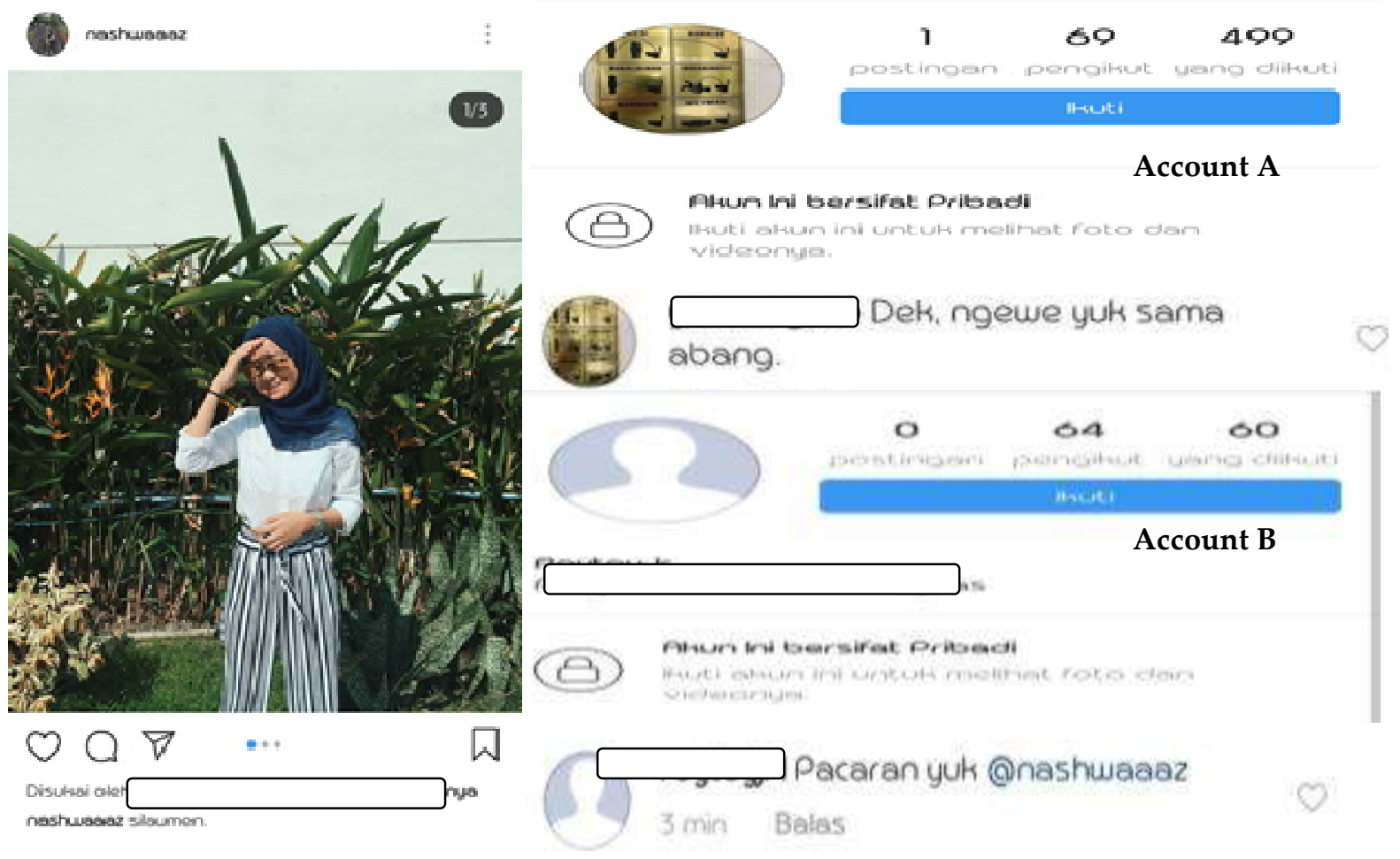

Based on the above account, you can see some comments leading to sexual harassment. One comment from account $\mathrm{A}$ is an expression of sexual harassment directly with the following words "Miss, let's $f^{* *} k "$. The researcher tried to open his account, but apparently the account was locked. Likewise with account B that writes comments that indirectly lead to sexual harassment, namely "come on dating with me". Then the researcher opened the profile of the account, but it turned out that the account was locked as well as account A. Researchers concluded that the owner of account A was writing comments leading to sexual harassment with the aim of getting attention from the victim's account and other netizens. It is based on the details in account A is 1 post, 69 followers, 499 followed and account B with details 0 posts, 64 followers, 60 followed and no profile photos. 
Attention is an activity that focuses mental resources on certain information (Santrock, 2012). Seeking attention is one of the characteristics of a teenager. Teenagers are not only influenced by culture, status-economy, and ethnics, but they are also influenced by the media. National research by Roberts, Foehr \& Rideout (2005) found that children and adolescents aged 8-18 years are now surrounded by social media. Teenagers around the world are increasingly dependent on the internet, although there are differences in their use in each individual (Shek, Tang, \& Lo, 2008).

Research by Pujazon-Zazik \& Park (2010) says that children and adolescents have not set special attention to access to social media information (internet). A national survey found that $42 \%$ of adolescents aged 10-17 years were exposed to pornography (Mitchell, Finkelhor \& Wolak 2007). Because of this phenomenon, harassment through social media tend to increase.

\section{Different perceptions of photo content or captions}

Photo content and captions of account owners do not lead to sexual matters, but netizens perceive it as something else.

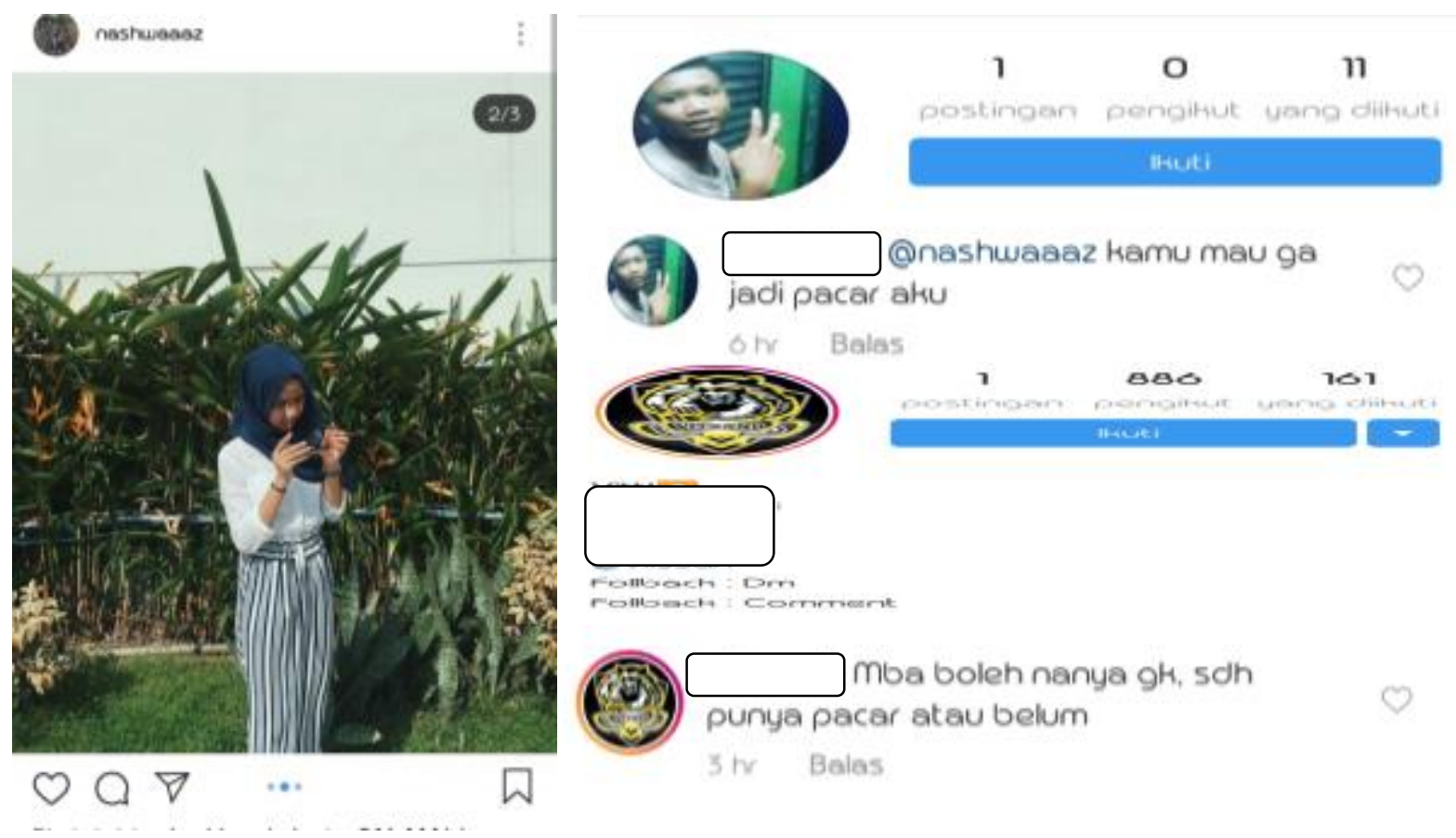

In the photo above, you can see some comments that do not match the caption and photo of the account owner. Comments are tempting and can lead to sexual harassment. Both accounts comment asking about the personal life of the account owner. In this case, it can be said that netizens have different perceptions with account owners. Perception is the process of regulating and interpreting sensory information to give a meaning (King, 2013). In this case, perception can arise due to physical attraction. As we know, individuals have physical attraction towards other individuals directly. However, research by Frazzetto 2010, Pujazon-Zazik \& Park, 2010 said physical attraction not only occurs because of direct interaction but also through social media. So this encourages individuals to ask personal questions that can lead to harassment of the account owner because it is tempting and disturbing. 


\section{Conclusions}

Sexual harassment is a form of harassment that makes individuals uncomfortable and disturbed. Forms of sexual harassment on social media can be; praising body shapes, throwing personal questions (concerning personal organs), sending photos, links or porn videos, asking victims to send naked photos or videos, threats of rape, solicitation of sexual relations, acknowledging making the victim's body a sexual image (Aprilia, 2017). This study is focused on sexual harassment on social media and found two forms; directly (explicitly in the comments) and indirectly (implied) based on the meaning of the sentence. Then, to answer the research questions the factors of sexual harassment on social media, it is known that there are two, namely; attention search and different perceptions between images among netizens. This factor occurs because of the large number of social media users who are teenagers, so they want the attention of the opposite sex due to physical attraction.

Suggestions based on this study are the need to develop psychoeducation for adolescents and families both as perpetrators and victims so they able to avoid sexual harassment behavior. Developing an intervention, such as psychoeducation, for adolescents and families could be an option to control individuals behavior between adolescents and families can be a control for individuals. This is because social media is a technology that requires supervision and rules from parents to teenagers who use it (Santrock, 2012).

\section{Acknowledgments}

This research on sexual harassment on social media will not be realized without the help of several parties. Thank you researchers for telling the Faculty of Psychology, Airlangga University, Surabaya, which provides full moral and material support. Second, to previous researchers who provided references for researchers so as to facilitate this research. Third, thank you researchers for saying to friends of the master of psychology at Airlangga University who always provide positive support. This work is our second work and we present it to IcomethNCP "International Conference of Mental Health, Neuroscience and Cyberpsychology". Critical criticism and suggestions need to improve this work further.

\section{References}

Alhabash, S. \& Ma, M. (2017). A Tale of Four Platform: Motivation And Uses of Facebook, Twitter, Instagram, and Snapchat Among College Students ?. Social Media + Society. 1-13. Doi $10.1177 / 2056305117691544$.

Aljohani, M., Nisbet, A., \& Blincoe, K. (2016). A Survey of Social Media Users Privacy Settings \& Information Disclosure. The Proceedings of 14th Australian Information Security Management Conference, 5-6 December, Edith Cowan University, Perth, Western Australia. 67-75. Doi 10.4225/75/58a693deee893

Aprillia, Intan. 2017. http://cewekbanget.grid.id/read/06864886/cewek-ini-pernah-mengalamipelecehan-seksual-di-media-sosial-ini-cara-menghadapinya?page=all accessed on 10 October 2018 
Fardouly, J., Willburger, B.K. \& Vertanian, L.R. (2017). Instagram Use and Young Women's Body Image Concerns and Self-Objectification: Testing Mediational Pathways. New Media \& Society. 20 (4), 1380-1395. Doi 10.1177/1461444817694499

Frazetto, Giovanni. (2010). The Science of Online Dating. Science and Society Journal. doi: 10.1038/embor.2009.264

Friska, Widianingrum. 2017. Perlindungan Hukum terhadap Anak Sebagai Korban Pelecehan Seksual. Repository: Universitas Muhammadiyah Yogyakarta

Gorkemli, N. (2017). Internet and Social Media Usage of Secondary School Students in Rural Areas. Manas Journal of Social Studies. 6 (1), 1-11. Doi

https://sport.detik.com/raket/d-4247884/asian-games-berlalu-jonatan-christie-dapat-bonus-dari-pbtangkas? ga=2.217914206.95939531.1539135208-1040874952.1539135208 accessed on 10 October 2018

https://www.statista.com/statistics/278414/number-of-worldwide-social-network-users/

https://www.theverge.com/2018/6/20/17484420/instagram-users-one-billion-count

Keipi, T., Koiranen, I., Koivula, A., \& Rasanen, P. (2018). Assessing The Social Media Landscape: Online Relational Use-Purposes and Life Satisfaction Among Finns. First Monday: PeerReviewed Journal On The Internet. 23 (1), Doi 10.5210/fm.v23i1.8128

King, Laura. (2013). The Science of Psychology “An Appreciateive View”. Jakarta: Salemba Humanika

Mitchell, K., Finkelhor, D. \& Wolak, J. (2007). Youth Internet Users at Risk for the Most Serious Online Sexual Solicitations. American Journal of Preventive Medicine, 32(6), pp.532-537

Pujazon - Zazik \& Park. (2010). To tweet, or not to tweet: gender differences and potential positive and negative health outcomes of adolescents' social internet use. American Journal of Men's Health. Doi 10.1177/1557988309360819.

Roberts, Foehr \& Rideout . (2005). Generation M: Media In The Lives Of 8 -18 Year- Olds. Kaiser Family Foundation

Ryan, T., Allen, K.A., Gray, D.L., \& McInerney, D.M. (2017). How Social Are Social Media? A Review of Online Social Behaviour and Connectedness. Journal of Relationships Research. 8 (e8), 1-8. Doi 10.1017/jrr.2017.13.

Santrock, JW. (2012). Life - Span Development "Perkembangan Masa Hidup". Edisi 13. Jakarta: Erlangga

Schenk, Samantha.2008. Cyber - Sexual Harassment: The Development of the Cyber - Sexual Experiences Questionnaire. McNair Scholars Journal. Volume 12: Grand Valley State University 
Sharifi, S.M., Omidi, A., \& Marzban, B. (2016). The Impact of Instagram Use on Body Image Concerns Among Iranian University Female Students: A Phenomenological Approach. International Journal of Academic Research In Psychology. 3 (1), 26-36. Doi 10.6007/IJARP/v3-i1/2280

Shek, D., Tang, V \& Lo, C. (2008). Internet Addiction in Chinese Adolescents in Hong Kong: Assesment, Profile, and Psychosocial Correlates. The Scientific World Journal. 8, 776-787

Waheed, H., Anjum, M., Rehman, M., \& Khawaja, A. (2017). Investigation of User Behavior on Social Networking Sites. Plos One. 12 (2), 1-19. Doi 10.1371/journal.pone.0169693

Wening, Andhika. 2018. http://sport.bisnis.com/read/20180828/59/832329/menang-di-final-asiangames-2018-jojo-buka-baju-dan-bikin-para-wanita-histeris accessed on 10 October 2018 